Revue internationale d'éducation de Sèvres

34 | décembre 2003

La formation professionnelle initiale: une question de société

\title{
États-Unis : les tendances actuelles de la recherche en éducation comparée
}

Pierre-Louis Gauthier

\section{OpenEdition}

\section{Journals}

Édition électronique

URL : https://journals.openedition.org/ries/1753

DOI : $10.4000 /$ ries. 1753

ISSN : 2261-4265

Éditeur

France Education international

Édition imprimée

Date de publication : 1 décembre 2003

Pagination : 162-169

ISBN : 978-2-8542-0558-9

ISSN : $1254-4590$

Référence électronique

Pierre-Louis Gauthier, «États-Unis : les tendances actuelles de la recherche en éducation comparée », Revue internationale d'éducation de Sèvres [En ligne], 34 I décembre 2003, mis en ligne le 23 novembre 2011, consulté le 09 juillet 2021. URL : http://journals.openedition.org/ries/1753 ; DOI : https://doi.org/ $10.4000 /$ ries. 1753

Ce document a été généré automatiquement le 9 juillet 2021.

(C) Tous droits réservés 


\title{
États-Unis : les tendances actuelles de la recherche en éducation comparée
}

\author{
Pierre-Louis Gauthier
}

1 La recherche en éducation connaît depuis plusieurs décennies un essor soutenu dans les institutions et universités américaines. Stimulée par les problèmes scolaires graves qu'a rencontrés la société américaine ${ }^{1}$, la recherche est soutenue par de puissantes institutions dont de prestigieuses universités. Elle est, de plus, fortement aidée par des instances privées et publiques. Ajoutons que le «11 septembre » et son caractère traumatisant dont les Européens n'ont pas toujours pris l'exacte mesure donne une sorte d'urgence dramatique aux recherches en éducation ${ }^{2}$.

2 Colloques, congrès et conférences foisonnent sur le continent américain. Lieux de controverse, ils répondent à cette nécessité du dissentiment, chère à la démarche scientifique. Les chercheurs y publient régulièrement leurs travaux en les soumettant à la validation de leurs pairs car, en contrepartie de réelles perspectives professionnelles, on attend de la recherche en éducation une production socialement visible. L'éducation comparée participe de ce développement. Ainsi, les colloques et congrès annuels de la CIES (Comparative and International Education Society), association américaine d'éducation comparée, permettent, à travers les exposés et symposiums, d'apprécier en temps réel l'état des recherches, les domaines privilégiés, les démarches et les méthodes. La recherche américaine en éducation comparée revêt une telle ampleur et une telle diversité, que ce serait une gageure de prétendre en dresser un tableau exhaustif. Du moins peut-on tenter d'en dégager les caractéristiques, tendances et perspectives actuelles.

\section{Des dimensions américaines}

Les dimensions de la recherche américaine en éducation comparée sont à l'échelle du continent. Au dernier congrès de la CIES en mars 2003, les participants venus de tous 
les États de l'Union et de quarante-quatre pays étrangers, qui se pressaient dans les salles de travail et de conférence, se voyaient offrir sept-cent-soixante-dix-huit communications, cinquante-quatre tables rondes, neuf conférences plénières, dix symposiums, quatre-vingt-cinq panels... Le nombre d'institutions représentées dépassait le millier. Cette quantité rejoint-elle la qualité ? Il est certes difficile d'affirmer que tous les travaux présentés relèvent bien de l'éducation comparée. Beaucoup s'apparentent autant à l'étude de cas qu'à la comparaison. Mais on peut affirmer que la liberté d'expression qui préside aux échanges permet d'inscrire les exposés dans une vaste confrontation comparative. On pourra en juger par les quelques exemples qui seront cités, choisis à titre d'illustration.

4 Autre caractéristique de la recherche américaine en éducation comparée, les terrains se répartissent sur tous les continents, sinon dans tous les pays. Les nombreux chercheurs de toutes origines, issus d'une immigration récente où dominent les Hispaniques et les Asiatiques, ont insufflé des orientations nouvelles à la recherche. Le grand nombre de chercheurs américains travaillant à l'étranger, accompagnant une politique étrangère et une expansion économique planétaires, renforcent encore cette tendance à l'ouverture. Les localisations géographiques de la recherche couvrent de fait le monde entier.

\section{Asie, Amérique, est européen : des zones privilégiées}

Trois zones sont privilégiées et l'on y trouve la plupart des pays émergents.

-L'Asie est très présente, avec de nombreuses comparaisons entre la Chine, le Japon, les dragons de Taiwan, la Corée du sud et Singapour. Les Philippines, la Thaillande, le Cambodge, le Vietnam viennent ensuite. L'Afghanistan et le Pakistan font l'objet de quelques études, ainsi que l'Inde. L'Australie et la Nouvelle-Zélande servent fréquemment de référence.

- L'Amérique donne lieu à des recherches croisées au Chili, Nicaragua, en Argentine, en Colombie, en Bolivie, au Brésil, au Guatemala, au Honduras, en Guyane, à Cuba et dans les Caraïbes. Le trio Canada, Mexique, États-Unis connaît un sort particulier en matière de comparaison depuis l'entrée en vigueur de l'Alena. Par contre, on remarquera qu'il existe peu d'études comparées inter- États-Unis.

- La troisième zone privilégiée concerne l'est européen et les systèmes éducatifs du postcommunisme en reconstruction. Les recherches comparatives sont nombreuses entre la Pologne, la Hongrie, la Roumanie, les Républiques tchèque et slovaque, les pays baltes et la Russie bien entendu. Cette considération s'applique aux ex-républiques soviétiques d'Asie centrale : l'Ouzbékistan, le Tadjikistan, le Kirghizstan, le Kazakhstan, l’Azerbaïdjan.

\section{Des zones moins étudiées}

- L'Afrique, avec des comparaisons concernant principalement l'Afrique orientale et australe : la Namibie, l'Ouganda, le Malawi, l'Éthiopie, l'Afrique du sud, Le Lesotho. L'Afrique subsaharienne est représentée avec des études concernant le Mali, le Ghana, la Sierra Leone, le Cameroun, le Nigéria.

- Le Maghreb, à l'exception du Maroc.

- Le Moyen-Orient, avec des études sur Israël, la Palestine, la Jordanie, l'Iran.

6 En Europe, quelques études concernent la Suède qui a toujours été un terrain de prédilection pour les chercheurs américains, l'Allemagne, l'Espagne et une 
comparaison entre l'Union européenne et les États-Unis. Les autres pays d'Europe occidentale ${ }^{3}$ sont quasiment absents des recherches actuelles. Signe des temps ?

7 Autre caractéristique, la diversité des échelles révèle une grande liberté de choix de la dimension des études. On trouve ainsi des travaux menés à l'échelle d'une classe, d'une école, d'une université, ou d'une ville, d'un État américain, d'une province, d'une communauté, d'un pays, d'un continent, au plan mondial enfin. Certes les études monographiques nationales l'emportent, mais les autres subdivisions et croisements, souvent d'une grande finesse, démontrent l'absence d'un modèle unique d'approche de la comparaison en éducation.

\section{Thèmes et problématiques}

8 Le choix des thèmes de recherche relève de la même diversité. Dans le foisonnement des aires conceptuelles qui en résulte, nous distinguerons huit groupes de paradigmes. Certains adaptent en fait des problématiques déjà anciennes à des données nouvelles, la mutation intervenant au fur et à mesure des développements socio-économiques et politiques. À partir de ce bouquet sont définies les problématiques appliquées à un cadre géographique déterminé. Une grande attention est portée à l'évolution de l'environnement éducationnel: "The relationship among parental factors, children's perception and achievement of urban youth ", (G.D. Perry, Michigan State University). Il faut souligner ici la forte interrelation des tendances socio-politiques et des priorités de la recherche américaine.

\section{La globalisation}

9 Ce thème représente de très loin le thème principal des recherches actuelles. Apparenté à maints sous-thèmes, on le retrouve en filigrane dans une majorité d'études. Il donne lieu à de nombreux croisements thématiques: "Exceptionalism, hegemony and bet-hedging: The paradox of US and Japanese approaches to the liberalization of trade in education ", (K. Mundy, Stanford University). L'influence des institutions nationales (l'Usaid) et internationales sur la recherche américaine a probablement accéléré les travaux relatifs à la globalisation. Citons parmi une vingtaine d'interventions de la Banque Mondiale: «Weak States and the struggle to develop education for a knowledge economy: Examples from Namibia and Zimbabwe ", (K.P. Dzimbo, World Bank).

\section{Les politiques éducatives}

10 Elles délimitent de nombreux ensembles thématiques au sein desquels la mise en pratique est souvent de rigueur.

\section{Politiques éducatives et gouvernance}

11 "Positioning teacher policy in African countries", (M.A. Sevilla, Michigan State University); "Curriculum reforms in Ethiopia, Japan, South Korea, Taiwan and the United States ", (S.S. Yoo, University of California) ; « Educational policy borrowing and stakeholder replacement: a Brazilian case study », (T.F. Luschei Stanford University); 
«The emerging State supervising model of governance and its impact on higher education performance in China », (L. Wang, New York University); «School autonomy in Nicaragua ", (I. Umansky, Harvard University). La décentralisation domine partout les évolutions et les réformes: c'est le cas au Japon: M. Yamashita, University of Pittsburgh ; en Argentine : G. Silvestre, University of Pittsburgh, S.A. Robert, University of Wisconsin; en Colombie: A. Minnici, University of Pittsburgh; en Thaillande: P. Busauwan, Loyola University-Chicago. Elle s'accompagne fréquemment de la privatisation: "Privatization in US", (A. Minnici, University of Pittsburgh); "The global privatisation of education: extreme ideology, rigid policy, and tenuous evidence ", (S.J. Klees, University of Maryland); "Educational privatization in comparative context », (H. Levin, Columbia University).

\section{Citoyenneté et démocratie}

"A preliminary analysis of school effects and civics knowledge", (D.P. Baker \& R. Fabrega, Pennsylvania State University); «The cross-national context of formal civics oriented programs", (A.W. Wiseman, University of Tulsa); «Ethnic diversity and citizenship education in multicultural nation states", (J.A.Banks, University of Washington); « Democracy achieved? A comparison of secondary students definitions of democracy in Czech and Slovak republics », (J. Bishop, Eastern Michigan University).

\section{Discours sur l'éducation}

Ils sont étudiés avec vigilance.

- Le discours nationaliste : "Globalization and news nationalisms », (S. Kamat, University of Massachusetts); «Some reflections over the nationalism discourse in the myths created by new oriental school », (H. Zhaqng, University of California).

- Le discours révisionniste : «Schools as sites to engage the living past? Memories lost, found, revised », (I.B.L. Goldstein, University of Kentucky).

- Le discours xénophobe et raciste : «Colonialism continued: African stu-dents in an urban high school in America", (R. Traore, Florida State University); "National and local ideologies in Japan », (U. Kinoshita, University of Wisconsin) ; "The meaning of whiteness and racial identity ", (J. Liu, University of San Diego).

- Le discours révolutionnaire: «Revolutionary education in Cuba and its impact in Latin America », (C.A. Torres, University of California).

- Le discours terroriste: "What should we tell educators about terrorism and Islam? Some considerations in the global context after September 11, 2001 », (M. Ginsburg, University of Pittsburgh); "National security, international students and the war on terrorism», (S. Akomolafe, Owen College).

\section{Politiques éducatives et droits de l'homme}

14 "Change in human rights discourse », (D. Suarez, Stanford Univer-sity); « Educational achievement from a human rights perspective», (N. Thapliyad, University of Maryland). 


\section{Politiques éducatives et économie}

15 L'impact des nouvelles technologies renforce la réflexion critique sur la commercialisation de l'éducation et ses profits. «An investment for whom? Lessons from a case study of high-technology corporations involment in the educational arena ", (H. Maldonado, Stanford University) ; «Too many teachers, too little money: the politics of teacher supply in parts of Central Asia », (D.W. Chapman, University of Minnesota).

\section{L'éducation pour tous}

16 « Progress or not? A comparative look at the texts of the EFA documents for Jomtien and Dakar », (V. Masemann, CIES President 1989).

\section{L'identité culturelle et linguistique}

17 La dominante culturelle regroupe des travaux relatifs au multiculturalisme, mais aussi au multilinguisme.

\section{L'interactivité entre les cultures}

Elle est au cœur des débats dans des contextes fort différents : «Intersections of policy, identity and language at an elite English-medium University in South Africa ", (J. Katunich, University of Michigan); "Comparing multi-cultural education policies in Japan and Germany », (C. Frey, Indiana University) ; «Contesting the accomplishments of the English-only policy in Malawian schools », (S. Shara, Michigan University); "Basque language revitalization and education: a comparative analysis of the Basque regions of France and Spain ", (K. Heidmann, University of Pittsburgh); "Teacher expectations in classrooms attended by indigenous children in Bolivia, Mexico and Peru », (E. Trevino, Harvard University) ; «Modernization of education and koranic adap-tation in Morocco ", (H.N. Boyle, Education Development Center).

\section{Résistance versus hégémonie}

19 Cette problématique est également fréquemment abordée : «Factors in resistance to instructional imperialism», (S.M. Che, University of Oklaoma); "A case study of Anatolia college: school ethnography in an era of globalization ", (R. Giampapa, Ohio State University) ; "Creole educations in the global borderlands of race and nation ", (D.B. Willis, Hamline University); "Colonialism and its impact on art education in Zambia », (J. Chanda, University of North Texas).

\section{Institutions internationales et standardisation de l'éducation} Spanish textbooks in the European Union and the United States », (A.B. Bartolomei, Loyola University, Chicago). 


\section{La sociologie de l'éducation}

Elle reprend généralement les thèmes de l'environnement scolaire.

- Les déviances en milieu scolaire

"School violence's influence on the teaching and learning process in urban schools ", (R. Duhon-SeLLs, University at New-Orleans).

- Secteur public et privé

"Private education in the Haitian education system », (S. Yasin, American Association of colleges for teacher education) ; «University missions/goals in the context of globalization: public and private institutions in the Middle East », (0. Obeidat, University of Pittsburgh).

- Les inégalités

"The illusion of equal and equitable access », (N. Norfles, PELL Institute) ; « Is educational equity possible? Black inferiority and alienation as policy-making agenda », (K.L. King, Auburn University).

- Les problèmes de santé

- « The prevalence of HIV/AIDS among students of color in institutions of higher education in South Africa and the United States: a comparative look », (T. Homan, Columbia University) ; "Associated myths of HIV/AIDS in Uganda and Africa ", (D.E. Morisky, University of California).

- La place de la religion

«Christians, Muslims, and non-believers in Russia », (V. Karpov, Western Michigan University).

- Milieu rural versus milieu urbain

"A case-study of educational transfer in rural Alaska », (T. Jester, Uni-versity of AlaskaAznchorage).

- Formation et travail

" The relationship between work experience and well-being among Mexican-origin youths ", (A.N. Olatunji, Dillard University, Nouvelle Orleans).

\section{L'éducation des femmes et des filles}

Elle fait l'objet d'une attention particulière: "Schools as a new social space for Jordanian adolescent girls », (F. Adely, Columbia University) ; «The post-war Japanese family and women: a content analysis of Japanese textbooks between 1952 and 2001 ", (K. Murakami, University of Kansas). Les sous thèmes sont en rapport avec la réalité de la condition féminine dans un contexte actuel: «Education as a preventive strategy against sexual exploitation for girls », (I. Martonova, World Education); «Voices of Peruvian women on sexual health: the Madres Cuidadoras », (F.V. La Serna, University of Southern California); "Iranian women's new identity ", (M. Derayeh, Concordia University). Les conséquences de la globalisation sur l'éducation des femmes sont examinées au Kenya (L. Mule, Smith College), en Tanzanie (F. Vavrus, Columbia University) et aux États-Unis (M.A. Maslak, St John's University).

\section{Les minorités}

Leur place dans les études est croissante, qu'il s'agisse de l'éducation ethnique, des "affirmatives actions", de l'éducation à distance: "Minority education policy and practices in Iran and Azerbaijan», (K. Lokkesmoe, University of Minnesota); 
"Negotiating the college instructor's role in the ethnically charged class-room », (C. Jandura, University of the Incarnate Word); "The Muslim Turks in German education ", (J. Coburn, University of Wisconsin-Madison. Concordia University) ; "China's ethnic minorities in higher education", (R. Clothey, University of Pittsburgh); "Effects of globalization on social identities of indigenous groups in Russia », (R.L. Raby, California Colleges for International Education) ; «Ethnic Koreans in P.R. China ", (S. Choi, Indiana University).

Les vastes mouvements de populations immigrantes et réfugiées de par le monde fournissent plusieurs recherches: "Educational opportunities for Afghan refugees ", (M. Kakkar, Concordia University); "Toward a case for refugee education research within a comparative paradigm », (B. Collet, Loyola University, Chicago) ; «Moroccan immigrants in Belgium ", (M. Merry, University of Wisconsin-Madison); " Politics vs. Meeting the Linguistic Needs of Immigrant Children », (D. Anderson \& D. Staub, Eastern Michigan University); «Refugee women as change agents », (C. Magno, Southern Connecticut State University).

\section{L'enseignement supérieur}

De nombreuses recherches concernent la qualité : «Quality in higher education »; (A. Chudgar, Stanford University), la standardisation: «Globalization and public higher education », (S. Keith, San Francisco State University) ; «Beyond Bologna: the politics of European Union educational standardization ", (A. Amaram, Stanford University); et la commercialisation: "The Mc Donaldization of higher education: the case of polytechnics in West Africa », (K. Banya, Florida International University).

Des croisements thématiques mettent en lumière les paradoxes de l'accès à l'enseignement supérieur dans les pays «faibles»: "Race, citizenship, and higher education: a comparative study of South Africa and the United States ", (M.C. Brown, Pennsylvania State University).

Enfin, la recherche en éducation, aux États-Unis comme en Europe, connaît une phase de redéfinition entre politique, idéologie et pratiques: «Ideology in educational research and policy making in the United States », (M. Moses, University of Arizona); «The impact of European Union educational policies: findings from an international research network », (H. Ertl, Paderborn University).

\section{L'éducation comparée comme objet d'études}

28 L'éducation comparée se prenant elle-même comme objet d'étude offre l'opportunité d'une réflexion sur ce champ disciplinaire en quête d'autonomie. Les différentes approches méthodologiques font l'objet d'une sorte de méta-comparaison dans un ensemble où la réflexion théorique n'exclut jamais l'enquête empirique : "The power of a collective metatheorical foundation: an examination of existing comparative and international education research paradigms ", (W.J. Jacob, University of California-Los Angeles). On s'interroge aussi sur les débouchés professionnels auxquels elle donne accès. Dans les conflits émergents, l'éducation comparée, en élucidant les différences, n'introduit-elle pas une certaine harmonisation et n'a-t-elle pas pour vocation de susciter l'apaisement et la résolution des conflits? "Community participation in education in a post conflict environment: the case of Guatelama », (J. Poe, George 
Washington University); "Afghanistan, education as a weapon», (M.M. Shorish, University of Illinois); " Freedom of speech and expression as catalysts for democratic change in post-war Sierra Leone », (S. Hinton, Eastern Kentucky University). comparaison en éducation. La résistance post-moderniste à certains paradigmes interpelle les études comparées et leur validité : «Global vs local, international vs globalization and the doing of comparative education ", (E.E. Gottlieb, Ohio State University).

Se pose d'une manière générale le positionnement périphérique de l'éducation comparée face à une large diffusion de la culture de la comparaison dans les sciences sociales aussi bien que dans les instances gouvernementales et internationales: "Teacher peripheriation in comparative education", (P.R. Fossum, University of Michigan-Dearborn). L'éducation comparée gagnerait à s'orienter davantage vers les questions d'éthique plutôt que vers les études de structures pratiquées par tant d'institutions.

La recherche américaine en éducation comparée fait donc la preuve d'une indéniable vigueur. Certes des carences existent. Ainsi la faible place de l'histoire, soulignée par plusieurs intervenants. Le manque d'indépendance de certaines recherches dû aux modes de financement, qui contraste singulièrement avec la liberté dont jouissent la plupart des chercheurs. S'il n'y a pas de tabous, des chasses gardées sont évidentes : la quasi-absence de la recherche européenne et de ses prés carrés francophone, hispanophone, germanophone, voire anglophone en est le signe. On en arrive à un dilemme posé à la communauté scientifique tout entière. Les modèles européens, avec leur exception culturelle et linguistique, peuvent-ils encore nourrir la réflexion de la recherche américaine? Dans le contexte de la globalisation, les chercheurs américains sont-ils en train de renoncer peu à peu à l'héritage européen au nom d'un universalisme dominant?

\section{NOTES}

1. A Nation at Risk, National Commission on Excellence in Education Report, US Department of Education, Washington DC, 1983.

2. 2. "Reassessing the Field of Comparative and International Education Post 9/11 and Rethinking What We Might Do in the Future », V. Masemann, CIES, 2003.

3. Seules une étude comparée sur les manuels scolaires européens et une recherche sur la langue basque mentionnent la France!

Revue internationale d'éducation de Sèvres, 34 | décembre 2003 
INDEX

Index géographique : États-Unis

\section{AUTEUR}

PIERRE-LOUIS GAUTHIER

Inspecteur d'académie $(\mathrm{H})$. 